\title{
Effect of Mulching and Supplemented Irrigation on Growth, Yield and Fruit Quality of Wood Apple (Feronia limonia Swingle)
}

\author{
Subrata Mahato $^{1 *}$, Subham Ghosh ${ }^{1,2}$ and Satya Narayan Ghosh ${ }^{1}$ \\ ${ }^{1}$ Department of Fruit Science, Faculty of Horticulture, Bidhan Chandra Krishi \\ Viswavidyalaya, West Bengal, India \\ ${ }^{2}$ Department of Health Family Welfare, Govt. of West Bengal, India \\ *Corresponding author
}

\begin{tabular}{l} 
Ke y w o r d s \\
Wood apple, \\
Mulching, \\
Irrigation, Plant \\
growth, Fruit yield \\
and quality \\
\hline Article Info \\
\hline $\begin{array}{l}\text { Accepted: } \\
\text { 17 September } 2020 \\
\text { Available Online: } \\
\text { 10 October } 2020\end{array}$ \\
\hline
\end{tabular}

\section{A B S T R A C T}

\section{Introduction}

India is the centre of origin for many fruit tree species, most of which are not commercially cultivated but provide a significant source of livelihood support for many rural communities. They are locally abundant, but restricted in their geographical dispersion and have a high use value. One of those is Wood apple (Feronia limonia Swingle syns. F. Elephantum correa; Limonia acidissima L.) a deciduous plant belongs to the family Rutaceae. It is also called monkey fruit, curd fruit and kathabel. It is reported to be native 
to India. The wood apple is mainly found in the forest and dry plain areas of Indian subcontinents. More common in Deccan, Maharashtra, Madhya Pradesh, also occurs from up to an elevation of about $500 \mathrm{~m}$ in the western Himalayas. It can grow in wide range of soils including degraded soils of arid region and it also tolerate to salinity and drought. Wood apple has got high medicinal value. Every part of the fruit posse's medicinal property. Fruit pulp has antiinflammatory, antipyretic and analgesic activity (Ahamed et al., 2008). Fruit used as a liver and cardiac tonic and when unripe, as an astringent means of halting diarrhoea and dysentery and effective treatment for hiccough, sore throat and diseases of the gums (Shil, 2019).The fruit plant is grown in poor soil and adverse climatic situation where fruit set and fruit drop is a common problem and moisture stress is may be one of the main reasons. To tackle this problem, providing water or conserving moisture to the root zone may be a good solution. Mulching plays an important role in the conservation of soil moisture during dry periods by reduction of water loss through evaporation, providing better nutrient availability, avoiding soil erosion, improve water and fertilizer use efficiency. Mulching also suppresses weed growth and provide nutrient to the plant and improve soil temperature. There are so many reports regarding beneficial effect of mulching and irrigation on fruit quality of arid fruit crops but such report on wood apple partially nil in India. With the view an investigation was conducted to know effect of mulching and supplemented irrigation on growth, yield and fruit quality of wood apple.

\section{Materials and Methods}

The present experiment entitled "Effect of mulching and supplemented irrigation on fruit quality of Wood apple" was conducted at Horticultural Research Station, Mondouri,
Bidhan Chandra Krishi Viswavidyalaya, Nadia, West Bengal, India during the period of 2016- 2018. The soil texture of the experimental field was sandy loam having 6.8 soil $\mathrm{pH}$ and the pre-experimental soil status has been presented in Table 1 .

The experimental sites were situated in the sub- tropical humid climate where summer and winter both are short and mild. So this region is not subjected to extreme winter. The climate of research station is sub-tropical humid with maximum temperature ranging from $35.62^{\circ} \mathrm{C}$ to $23.35^{\circ} \mathrm{C}$ and that of the minimum temperature ranging from $23.75^{\circ} \mathrm{C}$ to $8.09^{\circ} \mathrm{C}$ during the period of investigation. Major rainfall was received during the month of June and July. The relative atmosphere humidity prevailed during the period of experiment varied from $91.32 \%$ to $66.04 \%$. The experiments were laid out in a Randomized Block Design (RBD). Which comprised of five treatments viz., $\mathrm{T}_{1^{-}}$No mulching + No irrigation (control), $\mathrm{T}_{2^{-}}$Black polythene mulching + No irrigation, $\mathrm{T}_{3}$ - Black polythene mulching + irrigation @ 15 litres/ plant at 10 day interval, $\mathrm{T}_{4}-$ Black polythene mulching + irrigation@ 15 litres/ plant at 20 day interval, $\mathrm{T}_{5}-$ Black polythene mulching + irrigation@15 litres/plant at 30 day interval and each treatment has four replications. Total number of experimental plants is twenty (10 year old) and spacing is $5 \mathrm{~m} . \times 5 \mathrm{~m}$.Mulching was provided at first fortnight of November, 2016 and irrigation through basin was started from $3^{\text {rd }}$ February 2017 and continued up to $15^{\text {th }}$ June, 2017.

The plant growth parameter viz, plant height $(\mathrm{cm})$, girth $(\mathrm{m})$ and spread $(\mathrm{m})$ were collected from first week of February (before irrigation started), 2017 to last week of December. For fruit set percentage, 100 numbers of flowers are tagged after 30 days of flower opening and for fruit retention percentage, a 40 numbers of fruit tagged from marvel stage to 
harvesting and number of fruits per plant was calculated by counting at maturity from every plant. Fruit yield per plant and per hectare was calculated by multiplying number of fruits per plants with average fruit weight and multiplying fruit yield per plant with number of plants per hectare. For physical and chemical analysis of fruits, three fruits for each plant were collected randomly at mature stage. The length $(\mathrm{cm})$ and girth $(\mathrm{cm})$ of fruit were taken with the help of vernier callipers and a tape. Fruit weight (g) was taken with help of a balance and fruit pulp percentage was calculated. Total soluble solid content (TSS) of fruits estimated with the help of a digital hand refractometer (range 0- 53\%) and calibrated at $0^{\circ}$ Brix at $20^{\circ} \mathrm{C}$, Total titratable acidity content $(\%)$ of the fruits was estimated by titrating the aqueous extract of known quality of fruit juice against N/10 NaOH alkali solution using phenolphthalein as an indicator and expressed as percentage (Rusk, 1969).For vitamin $\mathrm{C}(\mathrm{mg} / 100 \mathrm{~g})$, total sugar (\%) and reducing sugar (\%) analysis of fruits, the methods were followed as described by A. O. A. C. (1984).

\section{Results and Discussion}

\section{Growth parameters}

Result of experiment showed that effect of black polythene mulching and irrigation significantly increased plant growth (Table 2) as compare to control $\left(\mathrm{T}_{1}\right)$. The highest trunk girth $(6.25 \mathrm{~cm})$, plant height $(0.56 \mathrm{~m})$ and plant spread (N-S $1.18 \mathrm{~m}$ and E-W $1.25 \mathrm{~m}$ ) were found in T3 treatment as compare to $\mathrm{T}_{1}$. Mulch and water plays an important role in the growth and development of plants. Mulching suppress weed growth and conserve soil moisture in the root zone of fruit trees. The presence of adequate amount of moisture in the soil is essential for plant growth and physiological processes. Increase water supply also increase growth rate of plants.
These results were in conformity with the findings of Shirgure et al., (2003) in Nagpur mandarin; Shukla et al., (2000) in aonla (Emblica officinalis) cv. NA-7 and Bhanukar et al., (2015) in Kinnow. In Nagpur mandarin (Shirgure et al., 2003) highest stock girth, scion girth, plant height and tree canopy volume were recorded in black polythene mulch. In aonla (Shukla et al., 2000) found that black polyethylene was the most effective inorganic mulching material for increasing plant height, canopy spread and stock girth compared to control. Bhanukar et al., 2015 found maximum per cent increase in plant spread EW (9.28) and NS (8.85) and plant height (8.52) was recorded with black polythene $200 \mu$. In Passion fruits, Rao et al., (2013) found longest vine growth $(176.00 \mathrm{~cm})$ in I1: irrigation at 10 days interval among all of different irrigation treatments.

\section{Yield Parameters}

It is evident from the data in Table 3 that fruit set, fruit retention, number of fruit, yield per plant and yield per hectare varied significantly. The highest fruit set (2\%), retention $(66.88 \%)$, fruit per plant $(78.25)$, yield per plant $(19.01 \mathrm{~kg})$ and yield per hectare (7.60 ton) was found in $\mathrm{T}_{3}$ and it is due to beneficial effect of black polythene mulching and irrigation. Mulch helped to conserve moisture that caused physiological changes for synthesis of metabolites, required for flowering and fruiting. Similar result found by Iqbal et al., (2016) in NA 7 cultivar of aonla. In their experiment, application of black polythene mulch was superior to all other mulching treatments in terms of yield attributes as it registered maximum fruit set, minimum fruit drop. Where maximum number of fruit per plant was due to highest retention of fruit. Water play a vital role during growth and development of fruits as water helps mobilization of nutrients and food materials to the growing fruits and mulching 
conserve soil moisture for longer duration and it also suppress weed growth which are result for loss of water from soil. Similar result was found by Ghosh and Pal (2010) in Mosambi; Panigrahi et al., (2010) in mango and Meghwal and Kumar (2014) in ber cv. Gola. In their experiment they were found that highest yield obtained from application of irrigation along with black polythene mulch.

\section{Physical and chemical parameters}

Data presented in Table 4 indicated that application of mulching and irrigation significantly increased fruit length $(7.72 \mathrm{~cm})$, fruit diameter $(24.33 \mathrm{~cm})$, fruit weight $(252.50 \mathrm{~g})$ and pulp content $(68.86 \%)$ were found in T3 (fruit length $6.2 \mathrm{~cm}$, fruit diameter $19.14 \mathrm{~cm}$, fruit weight $152.00 \mathrm{~g}$ and pulp content $64.15 \%$ ).

Table.1 Pre-experimental soil status

\begin{tabular}{|c|c|}
\hline Chemical properties & Values \\
\hline Available nitrogen (kg/ha) & 230 \\
\hline Available $\mathbf{P}_{\mathbf{2}} \mathbf{O}_{\mathbf{5}}$ (kg/ha) & 36 \\
\hline Available nitrogen $\mathbf{K}_{\mathbf{2}} \mathbf{O}$ (kg/ha) & 87 \\
\hline
\end{tabular}

Table.2 Effect of mulching and irrigation on growth rate of girth, height and spread of wood apple plant during 2017

\begin{tabular}{|c|c|c|c|c|}
\hline Treatments & $\begin{array}{c}\text { Girth growth } \\
(\mathbf{c m})\end{array}$ & $\begin{array}{c}\text { Height growth } \\
(\mathbf{m})\end{array}$ & $\begin{array}{c}\text { Plant spread from } \\
\mathbf{N - S}(\mathbf{m})\end{array}$ & $\begin{array}{c}\text { Plant spread from } \\
\text { E-W (m) }\end{array}$ \\
\hline $\mathbf{T}_{\mathbf{1}}$ & 4 & 0.38 & 0.63 & 0.64 \\
\hline $\mathbf{T}_{\mathbf{2}}$ & 5.13 & 0.44 & 0.88 & 0.80 \\
\hline $\mathbf{T}_{\mathbf{3}}$ & 6.25 & 0.56 & 1.18 & 1.25 \\
\hline $\mathbf{T}_{\mathbf{4}}$ & 5.88 & 0.49 & 1.04 & 0.98 \\
\hline $\mathbf{T}_{\mathbf{5}}$ & 5.38 & 0.48 & 0.94 & 0.88 \\
\hline $\mathbf{S E}(\mathbf{m}) \mathbf{\pm}$ & 0.43 & 0.03 & 0.08 & 0.10 \\
\hline C.D. at 5\% & 1.25 & 0.08 & 0.25 & 0.32 \\
\hline
\end{tabular}

Table.3 Effect of mulching and irrigation on yield and yield component of wood apple

\begin{tabular}{|c|c|c|c|c|c|}
\hline Treatments & Fruit set (\%) & $\begin{array}{c}\text { Fruit } \\
\text { Retention \% }\end{array}$ & $\begin{array}{c}\text { No. of fruits/ } \\
\text { plant }\end{array}$ & $\begin{array}{c}\text { Fruit yield/ } \\
\text { plant (Kg) }\end{array}$ & $\begin{array}{c}\text { Fruit yield } \\
\text { (ton/ha) }\end{array}$ \\
\hline $\mathbf{T}_{\mathbf{1}}$ & $0.50(1.21)$ & $51.25(45.70)$ & 49.00 & 5.99 & 2.40 \\
\hline $\mathbf{T}_{\mathbf{2}}$ & $1.25(1.49)$ & $58.13(49.67)$ & 70.50 & 13.51 & 5.40 \\
\hline $\mathbf{T}_{\mathbf{3}}$ & $2.00(1.72)$ & $66.88(54.87)$ & 78.25 & 19.01 & 7.60 \\
\hline $\mathbf{T}_{\mathbf{4}}$ & $1.50(1.57)$ & $63.75(52.97)$ & 74.00 & 15.96 & 6.39 \\
\hline $\mathbf{T}_{\mathbf{5}}$ & $1.25(1.49)$ & $61.25(51.56)$ & 69.75 & 14.04 & 5.61 \\
\hline $\mathbf{S E}(\mathbf{m}) \mathbf{\pm}$ & $0.25(0.24)$ & $2.65(1.58)$ & 4.67 & 0.94 & 0.38 \\
\hline C.D. at 5\% & $0.76(0.08)$ & $8.16(4.93)$ & 14.40 & 2.90 & 1.16 \\
\hline
\end{tabular}


Table.4 Effect of mulching and irrigation on physical and chemical characteristics of wood apple

\begin{tabular}{|c|c|c|c|c|c|c|c|c|c|}
\hline Treatments & $\begin{array}{c}\text { Length } \\
\text { (cm) }\end{array}$ & $\begin{array}{c}\text { Girth } \\
(\mathrm{cm})\end{array}$ & $\begin{array}{c}\text { Fruit } \\
\text { Weight } \\
\text { (g) }\end{array}$ & $\underset{\%}{\text { Pulp }}$ & $\begin{array}{c}\text { TSS } \\
\left({ }^{\circ} \text { Brix }\right)\end{array}$ & $\begin{array}{c}\text { Acidity } \\
(\%)\end{array}$ & $\begin{array}{c}\text { Vitamin } \\
\mathrm{C} \\
(\mathrm{mg} / \mathbf{1 0 0 g})\end{array}$ & $\begin{array}{c}\text { Total } \\
\text { sugar }(\%)\end{array}$ & $\begin{array}{l}\text { Reducing } \\
\text { Sugar }(\%)\end{array}$ \\
\hline $\mathbf{T}_{1}$ & 6.2 & 19.14 & 125.00 & 64.15 & 14.33 & 2.86 & 3.19 & 7.1 & 2.57 \\
\hline $\mathbf{T}_{2}$ & 7.28 & 22.14 & 196.25 & 66.11 & 16.13 & 2.72 & 3.75 & 7.53 & 2.63 \\
\hline $\mathbf{T}_{\mathbf{3}}$ & 7.72 & 24.33 & 252.50 & 68.86 & 17.10 & 2.46 & 4.69 & 8.14 & 2.84 \\
\hline $\mathbf{T}_{4}$ & 7.47 & 23.49 & 218.75 & 67.17 & 16.73 & 2.59 & 4.50 & 7.79 & 2.81 \\
\hline $\mathbf{T}_{5}$ & 7.29 & 21.80 & 206.25 & 66.70 & 16.38 & 2.66 & 4.13 & 7.68 & 2.80 \\
\hline $\mathrm{SE}(\mathrm{m}) \pm$ & 0.32 & 0.86 & 25.78 & 0.58 & 0.50 & 0.09 & 0.31 & 0.50 & 0.12 \\
\hline C.D. at $5 \%$ & 0.98 & 2.65 & 79.44 & 1.78 & 1.55 & NS & 0.95 & NS & NS \\
\hline
\end{tabular}

It may be due to increase of amount of water which result increase of volume of fruits. This result also near to Ghosh and Pal (2010) in Mosambi; Panigrahi et al., (2010) in mango in their report highest weight, size and pulp content found in irrigation along with black polythene mulch. A similar report also found by Bhanukar et al., (2015) in kinnow. The maximum fruit length, breadth and fruit weight were recorded with black polythene $200 \mu$ mulch.

Effect of black polythene mulching and irrigation on chemical composition of wood apple fruits helped to improve in TSS and Vitamin C of wood apple fruits significantly and black polythene mulching and irrigation @ 15litres/plant at 10 days interval was found the best in all case with $17.10^{\circ}$ brix, and $4.69 \mathrm{mg} / 100$ g compare to control (TSS $14.33^{\circ}$ brix and Vitamin C $3.19 \mathrm{mg} / 100 \mathrm{~g}$ ) (Table 4). The higher TSS recorded under black polythene mulching may be attributed due to better availability of nutrients, optimum soil moisture and temperature that might have been maintained due to mulching treatments. Similar result was found by Kumer et al., (2017) in karonda when they applied Black polythene mulching and irrigation (15 litre per plant) at 15 days interval and noted highest total soluble solids (22.01 ${ }^{\circ}$ Brix $)$ and vitamin C (16.05 mg/100g) as compared to other treatments. This result also near to Ghosh and Pal (2010) in Mosambi and Panigrahi et al., (2010) in mango. In mosombi vitamin $\mathrm{C}$ was highest of the plants received irrigation through drip at 0.8 Epan + polythene mulch and in mango TSS content was highest under drip irrigated treatment of $0.6 \mathrm{~V}$ volume of water with black polythene mulch.

Acidity, total sugar and reducing sugar content in the fruit were non- significant however, highest total sugar and reducing sugar content $(8.14 \%$ and $2.84 \%)$ with lowest acidity were found $(2.46 \%)$ in application of black polythene mulching + irrigation @ 15litres/plant at 10 days interval (Table 2). This results were also near to Kumer et al., (2017) in karonda where total sugar and reducing sugar found highest and acidity found lowest with the application of black polythene mulching and irrigation (15 litre per plant) at 15 days interval. These are in confirmed with the results noted by Ghosh and Pal (2010) in Mosambi. In their experiment result was non-significant but highest total sugars $(8.5 \%)$ found with irrigation through drip at 0.8 Epan + black polythene mulch.

In conclusion the results of the investigation revealed that a significant effect of mulching and irrigation on physical and chemical characteristic of wood apple fruits. Highest fruit weight, length, diameter, pulp contents, TSS, and Vitamin $\mathrm{C}$ were recorded from plant treated with black polythene mulching + irrigation @ 15 liters/plant at 10 days interval. Where acidity, total sugar and reducing sugar found nonsignificant. Lowest acidity, highest total sugar and reducing sugar were noted on application black polythene mulching + irrigation @ 15 liters/plant at 10 day's interval. There for it was 
concluded that black polythene mulching + irrigation@15 liters/ plant at 10 days interval was best treatment for increasing plant growth, yield and fruit quality of wood apple.

\section{References}

Ahamed, S.M, Swamy, S. K., Jayaverra, K.N., Rao, J.V., and Kumar, S. 2008. Anti inflammatory, antipyreticand analgesic activity of methanolic extract of Feronialimonia. Pharmacology. 3: 852-857

AOAC. 1984.Official Method of Analysis. Association of official Analytical Chemists. Washington, D.C.,U.S.A.

Bhanukar, M., Sindhu, S.S., Preeti, and Prince.2015. Effect of various mulches on growth, yield and quality of kinnow. The Bioscan an International Quarterly Journal of Life Sciences. 10(3): 1379-1382

Ghosh, S.N, and Pal, P.P. 2010. Effect of basin versus drip irrigation on quality production in Mosambi sweet orange. Journal of Horticultural Sciences. 5(1): 25-29

Iqbal, M., Bakshi, P., Wali, V. K., Kumar, R., Bhat, D., and Jasrotia, A. 2016. Efficacy of organic and inorganic mulching materials on weed count, growth and yield of Aonla (Emblica officinalis) cv. NA 7. Indian Journal of Agricultural Sciences. 86(4): 545549.

Kumar, P., Banik, B.C., Reshma, V.S., and Gupta, T.2017. Effect of Mulching and Supplementary Irrigation on Fruit Quality Characteristics of Karonda. International Journal of Pure Applied Bioscience.5(3):118-122

Meghwal, P.R., and Kumar, Pradeep.2014. Effect of supplementary irrigation and mulching on vegetative growth, yield and quality of ber.
India journal of horticulture. 71(4): 571-573

Morton, J.1987. Wood Apple. In: Fruits of Warm. Florida Flare Books. Pp. 190-191.

Panigrahi, H.K., Agrawal, N., Agrawal, R., Dubey, S., and Tiwari, S.P. 2010. Effect of drip irrigation and polythene mulch on the fruit yield and quality parametersof mango (Mangifera indica L.). J. Hortl. Sci.5 (2): 140-143

Patel, D.K., Kumar, R., Laloo, D., and Hemalatha, D.2012. Diabetes mellitus: An overview on its pharmacological aspects and reported medicinal plants having ant diabetic activity. Asian Pac. J.Trop. Biomed. 2(5): 411-420

Rao, B.N., Jha, A.K., Deo, C., Kumar, S., Roy, S. S., and Ngachan, S.V .2013. Effect of irrigation and mulching on growth, yield and quality of passion fruit (Passifloraedulis Sims.). Journal of Crop and Weed. 9(1): 9498

Rusk, J.A. 1969. Chemical methods for analysis of fruit and vegetables product, Research Station, Summerland, B.C. Canada Deptt. Of Agriculture.

Shil, Sanjoy.2019. Herbal Medicinal Plants: Their reputation and counteractive exploitation in traditional and modern medicines - A Review. International Journal of Agricultural Sciences and Veterinary Medicine.7 (1): 31- 45.

Shirgure, P.S., Sonkar, R.K., Singh, S., and Panigrahi, P.2003. Effect of different mulches on soil moisture conservation, weed reduction, growth and yield of drip irrigated Nagpur mandarin (Citrus reticulata). Indian Journal of Agricultural Sciences. 73 (3): 148-152

Troup, R.S. 1921. In: The silviculture of Indian trees, (Vol.III). Govt. of India Pub. 101-103.

\section{How to cite this article:}

Subrata Mahato, Subham Ghosh and Satya Narayan Ghosh. 2020. Effect of Mulching and Supplemented Irrigation on Growth, Yield and Fruit Quality of Wood Apple (Feronia limonia Swingle). Int.J.Curr.Microbiol.App.Sci. 9(10): 2479-2484. doi: https://doi.org/10.20546/ijcmas.2020.910.297 